Proceedings

\title{
A General Stereoselective Approach to 1,2,4-Triazepane-3-thiones/ones via Reduction or Reductive Alkylation of 2,4,5,6-Tetrahydro-3H-1,2,4- triazepine-3-thiones/ones ${ }^{\dagger}$
}

\author{
Anastasia A. Fesenko and Anatoly D. Shutalev* \\ N. D. Zelinsky Institute of Organic Chemistry, Russian Academy of Sciences, 47 Leninsky Ave., 119991 \\ Moscow, Russian Federation; af240182@yandex.ru \\ * Correspondence: anatshu@gmail.com; shad@ioc.ac.ru \\ + Presented at the 22nd International Electronic Conference on Synthetic Organic Chemistry, 15 November- \\ 15 December 2018; Available Online: https://sciforum.net/conference/ecsoc-22.
}

Published: 14 November 2018

\begin{abstract}
A general stereoselective approach to previously unknown 1,2,4-triazepane-3-thiones/ones based on reduction or reductive alkylation of readily available 2,4,5,6-tetrahydro-3H-1,2,4-triazepine3 -thiones/ones has been developed. The approach involved treatment of tetrahydrotriazepines with sodium cyanoborohydride in $\mathrm{MeOH}$ at $\mathrm{pH} 3$ or with sodium borohydride and excess of carboxylic acid in tetrahydrofuran to give 1-unsubstituted or 1-alkyl-substituted 1,2,4-triazepane-3thiones/ones, respectively. The latter were also prepared by reaction of 1-unsubstituted 1,2,4triazepane-3-thiones/ones with sodium cyanoborohydride and aldehyde in $\mathrm{MeOH}$ in the presence of $\mathrm{AcOH}$.
\end{abstract}

Keywords: 2,4,5,6-tetrahydro-3H-1,2,4-triazepine-3-thiones/ones; 1,2,4-triazepane-3-thiones/ones; reduction; reductive alkylation

\section{Introduction}

Development of efficient approaches to rare heterocyclic scaffolds is a fundamental challenge of organic synthesis and medicinal chemistry. 1,2,4-Triazepines, particularly 1,2,4-triazepin-3-ones/ thiones are representatives of these scaffolds [1-6]. They are of great interest because of their diverse pharmacological properties. For example, 1,2,4-triazepin-3-ones/thiones are effective antagonists of parathyroid hormone 1 (PTH1R) [7] and holecystokinin hormone 2 (CCK $)[8,9]$ receptors. Some of them possess antioxidant [10], antipsychotic [11,12], and HIV protease inhibitory activities [13-15].

The reported syntheses of 1,2,4-triazepin-3-ones/thiones include the reaction of $\beta$-isocyanato and $\beta$-isothiocyanato ketones with hydrazines [16-24], condensation of semicarbazides and thiosemicarbazides with various 1,3-dicarbonyl compounds or their derivatives [10,25-33], reaction of arylidene ketones with $\mathrm{N}_{2} \mathrm{H}_{4} \cdot 2 \mathrm{HNCS}$ [34], addition of semicarbazides and thiosemicarbazides to $\alpha, \beta$-unsaturated carbonyl compounds or their synthetic equivalents [35-39], reaction of $\gamma$-hydrazinosubstituted amines with phosgene equivalents $[8,13-15,40]$, and intramolecular cyclization of $4-(\gamma-$ oxoalkyl)semicarbazides and 4-( $\gamma$-oxoalkyl)thiosemicarbazides or their derivatives $[17,22,41,42]$. Generally, these methods give access to 1,2,4-triazepin-2- ones/thiones with one or two double bonds in the 7-membered ring. Their saturated representatives, particularly 1,2,4-triazepan-3-ones/ thiones 1 (Figure 1) remain practically inaccessible since the methods designed to produce these compounds mostly result in smaller-sized rings. For example, the condensation of 2-substituted thiosemicarbazides with 2,2-disubstituted malonyl chlorides was reported to give 5,7-dioxo-1,2,4- 
triazepane-3-thiones $[43,44]$. However, reinvestigation of this reaction showed that in most cases the only products formed were azetidine-2,4-diones [32], with the exception of the reaction between 2phenylthiosemicarbazide and 2,2-diethyl malonyl chloride affording the corresponding azetidine-2,4dione (59\%) along with 6,6-diethyl-5,7-dioxo-2-phenyl-1,2,4-triazepane-3-thione (2\%).
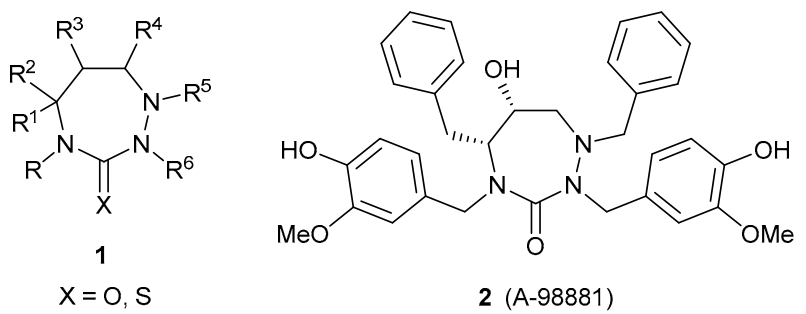

Figure 1. General formula of 1,2,4-triazepane-3-thiones/ones 1 and structure of nonpeptidic HIV protease inhibitor 2 .

The only relevant approach to triazepanes is based on the reaction of poorly available chiral nonracemic $\gamma$-hydrazino-substituted amines with phosgene equivalents to give the derivatives of 6hydroxy-1,2,4-triazepan-3-ones. It should be noted that these compounds are the key precursors for preparation of potent nonpeptidic HIV protease inhibitors (e.g., 2) [13-15].

Syntheses of triazepane-3-thiones/ones without functional groups at the 5, 6, and 7 positions, cyclic thiosemicarbazides, and semicarbazides, have not been reported. Thus, the development of reliable and practical approaches to non-functionalized triazepane-3-thiones/ones is of great interest from the viewpoint of synthetic, theoretical, and medicinal chemistry. We rationalized that these compounds could be prepared by reductive transformations of 2,4,5,6-tetrahydro-3H-1,2,4-triazepin2-ones/thiones. Previously, we developed effective syntheses of the latter based on acid-catalyzed cyclization of 4-(3-aryl-3-oxopropyl)(thio)semicarbazides and their hydrazones [18,42] or basepromoted ring expansion of 3-amino-4-hydroxyhexahydropyrimidine-2-thiones [19].

Here, we describe general stereoselective syntheses of previously unknown 1-unsubstituted or 1-alkyl substituted 1,2,4-triazepane-3-thiones/ones via reduction or reductive alkylation of tetrahydro-3H-1,2,4-triazepine-3-thiones/ones.

\section{Results and Discussion}

Readily available 2,4,5,6-tetrahydro-3H-1,2,4-triazepine-3-thiones/ones 3a-k $[18,19,42]$ served as starting material for the present investigation. Among a large variety of reductants which could be used for $\mathrm{C}=\mathrm{N}$ double bond reduction [45-50] we chose sodium cyanoborohydride [51-55]. We have found that triazepines 3a-k smoothly reacted with $\mathrm{NaBH}_{3} \mathrm{CN}$ (1.00-1.61 equiv.) in $\mathrm{MeOH}$ under slightly acidic conditions ( $\mathrm{pH}$ about 3) at room temperature to give the corresponding 1unsubstituted triazepanes $\mathbf{4 a -}-\mathbf{k}$ in high yields (Scheme 1, Table 1). The $\mathrm{pH}$ was maintained by the addition of $2 \mathrm{~N} \mathrm{HCl}$ in $\mathrm{MeOH}$ with methyl orange as an internal indicator.
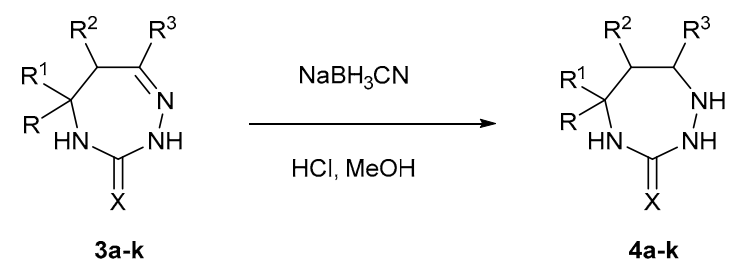

Scheme 1. Synthesis of 1-unsubstituted 1,2,4-triazepane-3-thiones/ones 4a-k.

The reduction rate strongly depended on the structure of triazepines $3 \mathbf{a}-\mathbf{k}$ and generally increased in the case of triazepin-3-ones compared with triazepine-3-thiones (Table 1; entry 5 vs. entry 6; entry 8 vs. entry 9; entry 10 vs. entry 11), 5-monosubstituted triazepines compared with 5,5- 
disubstituted ones (entry 3 vs. entries 4, 5, and 6; entry 7 vs. entry 8), and monocyclic triazepines compared with bicyclic ones (entries 1 and 2 vs. entries $4,5,6$, and 8).

Table 1. Synthesis of 1-unsubstituted 1,2,4-triazepane-3-thiones/ones $\mathbf{4 a - k}$ by reduction of $\mathbf{3 a}-\mathbf{k}$ with $\mathrm{NaBH}_{3} \mathrm{CN}$ in $\mathrm{MeOH}$ at room temperature $(\mathrm{pH} 3)^{a}$.

\begin{tabular}{|c|c|c|c|c|c|c|c|c|c|c|c|}
\hline Entry & 3 & $X$ & $\mathbf{R}$ & $\mathbf{R}^{1}$ & $\mathbf{R}^{2}$ & $\mathbf{R}^{3}$ & $\begin{array}{c}\text { Equiv. of } \\
\mathrm{NaBH}_{3} \mathrm{CN} \\
\end{array}$ & $\begin{array}{c}\text { Time } \\
\text { (h) }\end{array}$ & Product & $\begin{array}{c}\text { Isolated } \\
\text { Yield (\%) } \\
\end{array}$ & $\begin{array}{c}\text { cis/trans } \\
\text { Ratio }^{b}\end{array}$ \\
\hline 1 & $3 a$ & $S$ & Me & Me & $\mathrm{H}$ & $\mathrm{Me}$ & 1.00 & 1 & $4 a$ & 93 & - \\
\hline 2 & $3 b$ & $\mathrm{O}$ & $\mathrm{Me}$ & $\mathrm{Me}$ & $\mathrm{H}$ & $\mathrm{Me}$ & 1.00 & 1 & $4 b$ & 54 & - \\
\hline 3 & $3 c^{c}$ & $S$ & $\mathrm{Me}$ & $\mathrm{H}$ & \multicolumn{2}{|c|}{$\mathrm{CH}_{2} \mathrm{CH}_{2} \mathrm{CH}_{2}$} & 1.01 & 1 & $4 c$ & 94 & $-{ }^{d}$ \\
\hline 4 & $3 d$ & S & $\mathrm{Me}$ & $\mathrm{Me}$ & \multicolumn{2}{|c|}{$\mathrm{CH}_{2} \mathrm{CH}_{2} \mathrm{CH}_{2}$} & 1.48 & 3.17 & $4 d$ & 88 & $>99: 1$ \\
\hline 5 & $3 e$ & $S$ & \multicolumn{2}{|c|}{$\mathrm{CH}_{2} \mathrm{CH}_{2} \mathrm{CH}_{2}$} & \multicolumn{2}{|c|}{$\mathrm{CH}_{2} \mathrm{CH}_{2} \mathrm{CH}_{2}$} & 1.61 & 3.17 & $4 e$ & 92 & $>99: 1$ \\
\hline 6 & $3 f$ & $\mathrm{O}$ & \multicolumn{2}{|c|}{$\mathrm{CH}_{2} \mathrm{CH}_{2} \mathrm{CH}_{2}$} & \multicolumn{2}{|c|}{$\mathrm{CH}_{2} \mathrm{CH}_{2} \mathrm{CH}_{2}$} & 1.49 & 1 & $4 f$ & 91 & 99:1 \\
\hline 7 & $3 g^{e}$ & $S$ & $\mathrm{Me}$ & $\mathrm{H}$ & \multicolumn{2}{|c|}{$\mathrm{CH}_{2} \mathrm{CH}_{2} \mathrm{CH}_{2} \mathrm{CH}_{2}$} & 1.00 & 1 & $4 \mathrm{~g}$ & 84 & $-f$ \\
\hline 8 & $3 h$ & $S$ & $\mathrm{Me}$ & $\mathrm{Me}$ & \multicolumn{2}{|c|}{$\mathrm{CH}_{2} \mathrm{CH}_{2} \mathrm{CH}_{2} \mathrm{CH}_{2}$} & 1.50 & 1 & $4 h$ & 93 & $98: 2$ \\
\hline 9 & $3 \mathbf{i}$ & $\mathrm{O}$ & $\mathrm{Me}$ & $\mathrm{Me}$ & \multicolumn{2}{|c|}{$\mathrm{CH}_{2} \mathrm{CH}_{2} \mathrm{CH}_{2} \mathrm{CH}_{2}$} & 1.01 & 1 & $4 i$ & 94 & $88: 12$ \\
\hline 10 & $3 \mathbf{j}$ & S & $\mathrm{Ph}$ & $\mathrm{H}$ & $\mathrm{H}$ & $\mathrm{Ph}$ & 1.51 & 3 & $4 \mathbf{j}$ & 99 & $26: 74$ \\
\hline 11 & $3 k$ & $\mathrm{O}$ & $\mathrm{Ph}$ & $\mathrm{H}$ & $\mathrm{H}$ & $\mathrm{Ph}$ & 1.00 & 1 & $4 \mathrm{k}$ & 93 & 18:82 \\
\hline
\end{tabular}

${ }^{a}$ Level of conversion of the starting material is $100 \% .{ }^{b}$ According to ${ }^{1} \mathrm{H}$ NMR spectroscopic data for the crude product. ${ }^{c}$ A $92: 8$ mixture of $\left(5 R^{*}, 5 a R^{*}\right)$ - and $\left(5 S^{*}, 5 \mathrm{a} R^{*}\right)$-diastereomers (ref. [19]). ${ }^{d}$ A nearly pure $\left(5 R^{*}, 6 R^{*}, 7 R^{*}\right)$-diastereomer $(>96 \%)$. ${ }^{e} \mathrm{~A} 60: 40$ mixture of $\left(5 R^{*}, 5 \mathrm{a} R^{*}\right)$ - and $\left(5 S^{*}, 5 \mathrm{a} R^{*}\right)$-diastereomers (ref. [19]). ${ }^{f} \mathrm{~A}$ mixture of $\left(5 R^{*}, 6 R^{*}, 7 R^{*}\right)$ - and $\left(5 R^{*}, 6 S^{*}, 7 S^{*}\right)$-diastereomers in a ratio of $60: 40$, respectively.

Reduction of the $\mathrm{C}=\mathrm{N}$ bond in $\mathbf{3} \mathbf{a}-\mathbf{k}$ results in formation of a new stereocenter at the $\mathrm{C} 7$ atom. Diastereoselectivity of this reaction varies from good to excellent (Table 1). Due to strong 1,2asymmetric induction bicyclic triazepines $\mathbf{3} \mathbf{d}-\mathbf{f}$,h gave practically single $\left(6 R^{*}, 7 S^{*}\right)$-diastereomers of triazepanes $\mathbf{4 d} \mathbf{d}-\mathbf{f}, \mathbf{h}$ with cis-relationship between two rings (cis/trans $\geq 98: 2$ ) (entries $4-6$, and 8 ). With triazepine $3 \mathbf{i}$ the reaction diastereoselectivity slightly decreased, and a mixture of cis- and transisomers of $4 \mathbf{i}$ was obtained in a ratio of 88:12 (entry 9). Reduction of diphenyl-substituted monocyclic triazepines $3 \mathbf{j}, \mathbf{k}$ showed further decrease in selectivity to result in mixtures of cis- and transdiastereomers of triazepanes $\mathbf{4 j}, \mathbf{k}$ in a ratio of $74: 26$ and 82:18, respectively (entries 10 and 11).

Next, we studied reduction of bicyclic 5-methyl triazepines $3 \mathrm{c}$ and $3 \mathrm{~g}$ possessing two stereocenters which were obtained as mixtures of two diastereomers in a ratio of 92:8 and 60:40, respectively [19]. We have found that practically single $\left(5 R^{*}, 6 R^{*}, 7 R^{*}\right)$-diastereomer $(>96 \%)$ of $4 \mathrm{c}$ formed in $94 \%$ yield from $3 \mathrm{c}$ (entry 3 ) and a $60: 40$ mixture of $\left(5 R^{*}, 6 R^{*}, 7 R^{*}\right)$ - and $\left(5 R^{*}, 6 S^{*}, 7 S^{*}\right)$ diastereomers of $\mathbf{4 g}$ formed in $84 \%$ yield from $\mathbf{3 g}$ (entry 7 ). With both triazepines $\mathbf{3} \mathbf{c}$ and $\mathbf{3 g}$ strong 1,2-asymmetric induction led exclusively to triazepanes $\mathbf{4 c ,} \mathbf{g}$ with cis-relationship between two rings. Based on these data, the relative configuration of the major and minor isomers of starting compounds $3 \mathrm{c}, \mathbf{g}$ could be unambiguously assigned as $\left(5 R^{*}, 5 \mathrm{a} R^{*}\right)$ and $\left(5 S^{*}, 5 \mathrm{a} R^{*}\right)$, respectively [19].

We suppose that the first step of the reduction of triazepines $\mathbf{3} \mathbf{a}-\mathbf{k}$ under the described conditions is protonation of either the oxo/thioxo-group or the imino nitrogen affording hydrochlorides $\mathbf{5 a}-\mathbf{k}$ or 6a-k, respectively (Scheme 2).

The density functional theory calculations performed at the B3LYP/6-311++G(d,p) level of theory for cations $\mathbf{5 d}, \mathbf{h}, \mathbf{i}, \mathbf{k}$ and $\mathbf{6 d}, \mathbf{h}, \mathbf{i}, \mathbf{k}$ with pseudo-axial and pseudo-equatorial orientation of the 5-Ph group (for $5 \mathbf{k}$ and $\mathbf{6 k}$ ) or $\mathrm{C} 6-\mathrm{CH}_{2}$ bond (for $\mathbf{5 d}, \mathbf{h}, \mathbf{i}$ and $\mathbf{6 d}, \mathbf{h}, \mathbf{i}$ ) using the polarizable continuum model showed that the $N$-protonated cations $\mathbf{6} \mathbf{d}, \mathbf{h}, \mathbf{i}, \mathbf{k}$ are significantly more stable than the corresponding $O$ - or $S$-protonated cations $\mathbf{5} \mathbf{d}, \mathbf{h}, \mathbf{i}, \mathbf{k}(1.8-8.1 \mathrm{kcal} / \mathrm{mol}$ in $\mathrm{MeOH})$. Therefore, formation of $\mathbf{5 a}-\mathbf{k}$ can be excluded. The final step of the reaction is hydride transfer from $\mathrm{NaBH}_{3} \mathrm{CN}$ to the initially generated hydrochlorides $\mathbf{6} \mathbf{a}-\mathbf{k}$ to give the target products $\mathbf{4 a}-\mathbf{k}$. 

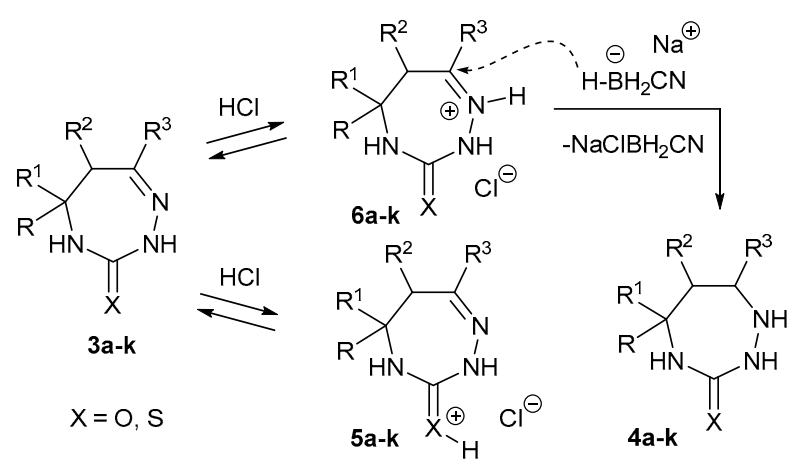

Scheme 2. A plausible pathway for the reduction of $3 \mathbf{a}-\mathbf{k}$ into $4 \mathbf{a}-\mathbf{k}$.

High diastereoselectivity in the reduction of $\mathbf{3} \mathbf{c}-\mathbf{k}$ can be explained in terms of steric approach control. The equatorial attack of the reducing reagent to the imine carbon of intermediate cations $\mathbf{6 c}-$ $\mathbf{k}$ is preferable. The axial attack is complicated by van der Waals repulsions with two axial cyclohexane hydrogens in $\mathbf{6 g}-\mathbf{i}$, two pseudo-axial cyclopentane hydrogens in $\mathbf{6 c - f}$ or pseudo-axial 5$\mathrm{H}$ hydrogen in $\mathbf{6 j}, \mathbf{k}$. This conclusion is confirmed by the DFT B3LYP/6-311++G(d,p) optimized geometries (in $\mathrm{MeOH}$ ) of the most stable conformers of cations $\mathbf{6} \mathbf{d}, \mathbf{h}, \mathbf{i}, \mathbf{k}$ with pseudo-axial and pseudo-equatorial position of the 5-Ph group (for $\mathbf{6 k}$ ) or $\mathrm{C}_{-}-\mathrm{CH}_{2}$ bond (for $\mathbf{6 d}, \mathbf{h}, \mathbf{i}$ ). Three representative examples with favored (a) and unfavored (b) attack of $\mathrm{BH}_{3} \mathrm{CN}$-anion to the equatorial conformers of cations $\mathbf{6} \mathbf{d}, \mathbf{i}, \mathbf{k}$ are shown in Figure 2.

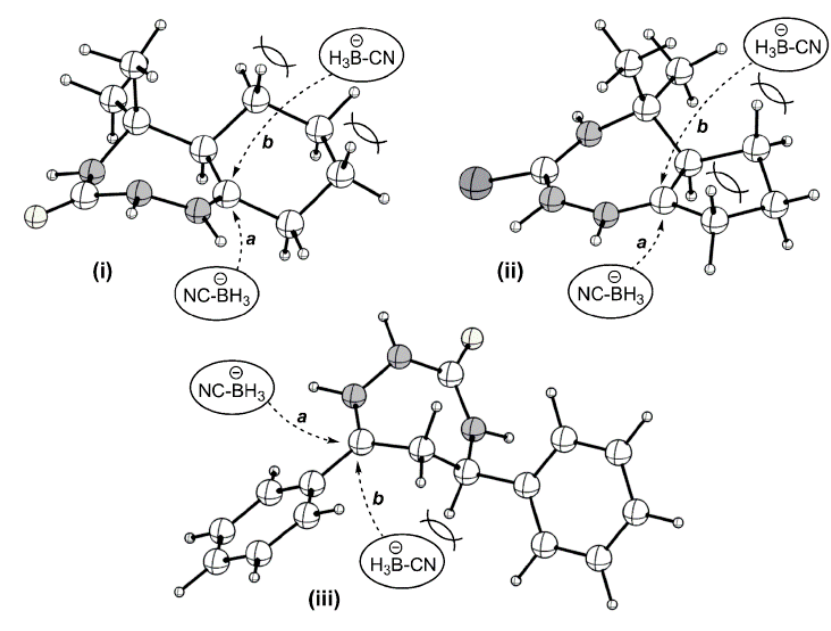

Figure 2. Favored (a) and unfavored (b) approach of $\mathrm{BH}_{3} \mathrm{CN}$-anion to $\mathrm{N}$-protonated triazepines: $6 \mathbf{i}(\mathbf{i})$, 6d (ii), and 6k (iii).

Crude triazepanes $\mathbf{4 a}-\mathbf{k}$ were purified by crystallization (for $\mathbf{4 a}, \mathbf{d}-\mathbf{f}, \mathbf{h}-\mathbf{j}$ ) or using silica gel column chromatography followed by crystallization (for $\mathbf{4 b}, \mathbf{c}, \mathbf{g}, \mathbf{k}$ ). It should be noted that after purification triazepanes $\mathbf{4} \mathbf{c}-\mathbf{f}, \mathbf{h}, \mathbf{j}, \mathbf{k}$ were obtained as practically single diastereomers $(d r \geq 95 \%)$.

The structure of compounds $4 \mathrm{a}-\mathrm{k}$ was established by spectroscopic data. The ${ }^{1} \mathrm{H}$ NMR spectra of $4 \mathbf{a}-\mathbf{k}$ in DMSO- $d_{6}$ show a long-range coupling between the (thio)amide $\mathrm{N}(2) \mathrm{H}$ and $\mathrm{N}(4) \mathrm{H}$ protons $\left({ }^{4} \mathrm{~J}=2.0-2.5 \mathrm{~Hz}\right)$ that indicates their one-plane $\mathrm{W}$-shaped arrangement. Similar long-range couplings are characteristic of $\mathrm{N}$-unsubstituted (thio)ureide-containing heterocycles, e.g., 2,3,4,5-tetrahydroand 2,3-dihydro-1H-1,3-diazepin-2-ones [56-60], hexahydro- and 1,2,3,4-tetrahydropyrimidine-2thiones/ones [56-67], 2,4,5,6-tetrahydro-3H-1,2,4-triazepine-3-thiones/ones [18,19,42]. Signal of the $\mathrm{N}(1) \mathrm{H}$ proton in $\mathbf{4 a}-\mathbf{k}$ appears as a doublet of doublets at $4.23-6.36 \mathrm{ppm}$ with vicinal couplings ${ }^{3} \int_{\mathrm{N}(1) \mathrm{H}, \mathrm{N}(2) \mathrm{H}}=0-3.5$ and $3{ }^{3} \mathrm{~N}(1) \mathrm{H}, \mathrm{H}-7=4.2-11.1 \mathrm{~Hz}$. The relative configurations of the stereogenic centers in $4 \mathbf{c}, \mathbf{d}, \mathbf{f}, \mathbf{i}-\mathbf{k}$ and the minor isomers of $4 \mathrm{~g}$, $\mathbf{h}$ were assigned based on the analysis of couplings between protons of the triazepane ring. For example, high values of vicinal couplings between the H-5 and H6 protons $(10.5 \mathrm{~Hz})$ and between the $\mathrm{H}-7$ and $\mathrm{N}(1) \mathrm{H}$ protons $(10.8 \mathrm{~Hz})$ in $4 \mathrm{c}$ indicate that these protons 
are antiperiplanar, and therefore, this compound has $\left(5 R^{*}, 6 R^{*}, 7 R^{*}\right)$-configuration. The cisrelationship between the cyclopentane and triazepane rings in $4 \mathrm{c}$ is also confirmed by a relatively high value of vicinal coupling between the H-6 and H-7 protons $(8.2 \mathrm{~Hz})$. High values of vicinal couplings ${ }^{3} \mathrm{H}-5, \mathrm{H}-6=10.5 \mathrm{~Hz}$ and ${ }^{3} \mathrm{H}-6, \mathrm{H}-7=10.8 \mathrm{~Hz}$ observed in the ${ }^{1} \mathrm{H}$ NMR spectrum of the minor diastereomer of $4 \mathbf{j}$ prove that two phenyl groups have cis-arrangement. The major diastereomer of $4 \mathbf{j}$ has trans-configuration with a pseudo-axial orientation of the 5-Ph group $\left({ }^{3} \int_{\mathrm{N}(4) \mathrm{H}, \mathrm{H}-5}=5.2,{ }^{3} \mathrm{H}_{\mathrm{H}-5, \mathrm{H}-6}=2.5\right.$ $\mathrm{Hz})$ and a pseudo-equatorial orientation of the 7-Ph group $\left({ }^{3} \mathrm{H}-6, \mathrm{H}-7=9.2 \mathrm{~Hz}\right)$.

Two alternative procedures were developed for preparation of 1-alkyl-substituted 1,2,4triazepane-3-thiones/ones. The first involves reductive alkylation of 2,4,5,6-tetrahydro-3H-1,2,4triazepine-3-thiones/ones 3 with sodium borohydride in carboxylic acid media [68-71]. We found that monocyclic triazepines $3 \mathbf{a}, \mathbf{b}$ smoothly reacted with $\mathrm{NaBH}_{4}$ (6 equiv.) in the presence of $\mathrm{AcOH}$ or $\mathrm{EtCOOH}$ (60.3-61.9 equiv.) in THF at room temperature for 23.5-24 h to give the corresponding 1ethyl- or 1-propyltriazepanes $\mathbf{7 a , b}, \mathbf{b}, \mathbf{e}, \mathbf{f}$ in $50-90 \%$ yields (Scheme 3; Table 2, entries 1, 2, 6, and 7).

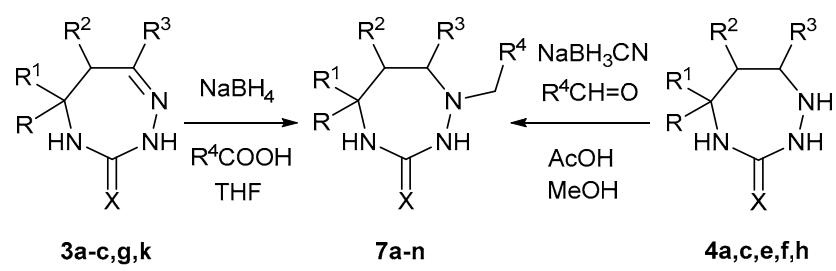

Scheme 3. Synthesis of 1-alkyl-substituted 1,2,4-triazepane-3-thiones/ones $7 \mathbf{a}-\mathbf{n}$ by the reductive alkylation.

Under similar conditions (THF, rt, 24 h), the reaction of diphenyl triazepine $3 \mathbf{k}$ with $\mathrm{NaBH}_{4}(5.9$ equiv.) in the presence of $\mathrm{AcOH}$ (63.4 equiv.) gave a mixture of starting material $3 \mathbf{k}$ and 1 ethyltriazepane $\mathbf{7 n}$ in a ratio of $21: 79$, respectively. This reaction was completed with 10 equivalents of $\mathrm{NaBH}_{4}$ and 108.3 equivalents of $\mathrm{AcOH}$ to produce the target $\mathbf{7 n}$ in $94 \%$ yield with excellent transdiastereoselectivity (trans:cis $=98: 2$, Table 2, entry 16). Higher stereoselectivity in the reduction of $\mathbf{3 k}$ with $\mathrm{NaBH}(\mathrm{OAc})_{3}$, in situ generated from $\mathrm{NaBH}_{4}$ and $\mathrm{AcOH}$ [68], compared with $\mathrm{NaBH}_{3} \mathrm{CN}$ (trans:cis $=82: 18$, Table 1, entry 11) can be explained in terms of steric approach control (see Figure 2) considering a greater steric bulk of reducing reagent in the first case.

Cyclohexane-fused triazepine $3 \mathrm{~g}$ [a $60: 40$ mixture of $\left(5 R^{*}, 5 \mathrm{a} R^{*}\right)$ - and $\left(5 S^{*}, 5 \mathrm{a} R^{*}\right)$-isomers] reacted with $\mathrm{NaBH}_{4}$ (6.1 equiv.) in the presence of $\mathrm{AcOH}$ (65.4 equiv.) or $\mathrm{EtCOOH} \mathrm{(62.2} \mathrm{equiv.)} \mathrm{in} \mathrm{THF} \mathrm{(rt,} 24$ h) with very high stereoselectivity to give mixtures $\left(5 R^{*}, 6 R^{*}, 7 R^{*}\right)$ - and $\left(5 S^{*}, 6 R^{*}, 7 R^{*}\right)$-diastereomers (cis-relationship between two rings) of triazepanes $\mathbf{7 k}, \mathbf{1}$ in a ratio of $61: 39$ and $58: 42$, respectively (entries 13 and 14). Reduction of cyclopentane-fused triazepine 3c also proceeded with very high stereoselectivity but the reaction rate relatively decreased. Under optimized conditions, the reaction between this compound [a 92:8 mixture of $\left(5 R^{*}, 5 \mathrm{a} R^{*}\right)$ - and $\left(5 S^{*}, 5 \mathrm{a} R^{*}\right)$-isomers] and $\mathrm{NaBH}_{4}$ (10 equiv.) in the presence of $\mathrm{AcOH}\left(104\right.$ equiv.) (THF, rt, $24 \mathrm{~h}$ ) afforded a $91: 9$ mixture of $\left(5 R^{*}, 6 R^{*}, 7 R^{*}\right)$ - and $\left(5 S^{*}, 6 R^{*}, 7 R^{*}\right)$-diastereomers of $\mathbf{7 g}$ with cis-fused rings (entry 8$)$.

The alternative approach to 1-alkyl-substituted 1,2,4-triazepane-3-thiones/ones 7 involves reductive alkylation of their 1-unsubstituted analogs 4 under the action of aldehyde and $\mathrm{NaBH}_{3} \mathrm{CN}$ in the presence of $\mathrm{AcOH}$ (Scheme 3). Treatment of $\mathbf{4 a}, \mathbf{c}, \mathbf{e}, \mathbf{h}$ with aliphatic aldehydes (5.8-6.4 equiv.), $\mathrm{NaBH}_{3} \mathrm{CN}$ (1.5-1.6 equiv.) and $\mathrm{AcOH}$ (1.5 equiv.) in $\mathrm{MeOH}$ at room temperature for $2 \mathrm{~h}$ resulted in the corresponding triazepanes $\mathbf{7 b} \mathbf{b}, \mathbf{c}, \mathbf{g}, \mathbf{h}, \mathbf{j}, \mathbf{m}$ in high yields (Table 2, entries $3,4,9,10,12$, and 15). Under the same conditions, compounds $4 \mathbf{a}$,e were reacted with benzaldehyde (6.1 equiv.), $\mathrm{NaBH}_{3} \mathrm{CN}$ (3.13.6 equiv.) and $\mathrm{AcOH}$ (3.0-3.1 equiv.) to give triazepanes $\mathbf{7 d}$,i in 90 and $93 \%$ yields, respectively (entries 5 and 11). 
Table 2. Synthesis of 1-substituted 1,2,4-triazepane-3-thiones/ones 7a-n by the reductive alkylation of $3 \mathbf{a}-\mathbf{c}, \mathbf{g}, \mathbf{k}$ and $4 \mathbf{a}, \mathbf{c}, \mathbf{e}, \mathbf{f}, \mathbf{h}{ }^{a}$.

\begin{tabular}{|c|c|c|c|c|c|c|c|c|c|c|c|}
\hline Entry & 3 or 4 & $x$ & $\mathbf{R}$ & $\mathbf{R}^{1}$ & $\mathbf{R}^{2}$ & $\mathbf{R}^{3}$ & $\mathbf{R}^{4}$ & Reaction conditions ${ }^{b}$ & 7 & $\begin{array}{l}\text { Yield } \\
(\%) c\end{array}$ & $\mathrm{dr}{ }^{d}$ \\
\hline 1 & $3 a$ & $S$ & $\mathrm{Me}$ & $\mathrm{Me}$ & $\mathrm{H}$ & $\mathrm{Me}$ & $\mathrm{Me}$ & $\begin{array}{c}\mathrm{NaBH}_{4}(6.0), \mathrm{AcOH}(61.1) \\
\text { THF, rt, } 24 \mathrm{~h}\end{array}$ & $7 a$ & 89 & - \\
\hline 2 & $3 a$ & S & $\mathrm{Me}$ & $\mathrm{Me}$ & $\mathrm{H}$ & $\mathrm{Me}$ & Et & $\begin{array}{c}\mathrm{NaBH}_{4} \text { (6.0), EtCOOH (61.9), } \\
\text { THF, rt, } 24 \text { h }\end{array}$ & $7 \mathrm{~b}$ & 90 & - \\
\hline 3 & $4 a$ & S & $\mathrm{Me}$ & $\mathrm{Me}$ & $\mathrm{H}$ & $\mathrm{Me}$ & Et & $\begin{array}{c}\mathrm{NaBH}_{3} \mathrm{CN} \text { (1.5), } \mathrm{EtCHO} \\
\text { (5.8), } \mathrm{AcOH}(1.5), \mathrm{MeOH}, \mathrm{rt}, \\
2 \mathrm{~h}\end{array}$ & $7 \mathrm{~b}$ & 90 & - \\
\hline 4 & $4 a$ & S & $\mathrm{Me}$ & $\mathrm{Me}$ & $\mathrm{H}$ & $\mathrm{Me}$ & $\operatorname{Pr}$ & $\begin{array}{c}\mathrm{NaBH}_{3} \mathrm{CN} \text { (1.5), } \mathrm{PrCHO} \\
\text { (6.0), } \mathrm{AcOH} \text { (1.5), } \mathrm{MeOH}, \mathrm{rt}, \\
2 \mathrm{~h}\end{array}$ & $7 \mathrm{c}$ & 95 & - \\
\hline 5 & $4 a$ & S & $\mathrm{Me}$ & $\mathrm{Me}$ & $\mathrm{H}$ & $\mathrm{Me}$ & $\mathrm{Ph}$ & $\begin{array}{c}\mathrm{NaBH}_{3} \mathrm{CN} \text { (3.6), } \mathrm{PhCHO} \\
\text { (6.1), } \mathrm{AcOH} \text { (3.0), } \mathrm{MeOH}, \mathrm{rt}, \\
2 \mathrm{~h}\end{array}$ & $7 \mathrm{~d}$ & 90 & - \\
\hline 6 & $3 b$ & $\mathrm{O}$ & $\mathrm{Me}$ & $\mathrm{Me}$ & $\mathrm{H}$ & $\mathrm{Me}$ & $\mathrm{Me}$ & $\begin{array}{c}\mathrm{NaBH}_{4}(6.0), \mathrm{AcOH}(60.3) \\
\mathrm{THF}, \mathrm{rt}, 24 \mathrm{~h}\end{array}$ & $7 e$ & 50 & - \\
\hline 7 & $3 b$ & $\mathrm{O}$ & $\mathrm{Me}$ & $\mathrm{Me}$ & $\mathrm{H}$ & $\mathrm{Me}$ & Et & $\begin{array}{c}\mathrm{NaBH}_{4} \text { (6.0), EtCOOH (60.6), } \\
\text { THF, rt, } 23.5 \text { h }\end{array}$ & $7 \mathrm{f}$ & 50 & - \\
\hline 8 & $3 c^{e}$ & S & $\mathrm{Me}$ & $\mathrm{H}$ & $\mathrm{CH}_{2}$ & $\mathrm{CH}_{2}$ & $\mathrm{Me}$ & $\begin{array}{c}\mathrm{NaBH}_{4}(10.1), \mathrm{AcOH}(104.1), \\
\text { THF, rt, } 24 \text { h }\end{array}$ & $7 \mathrm{~g}$ & 31 & $-f$ \\
\hline 9 & $4 c$ & S & $\mathrm{Me}$ & $\mathrm{H}$ & $\mathrm{CH}_{2}$ & $\mathrm{CH}_{2}$ & $\mathrm{Me}$ & $\begin{array}{c}\mathrm{NaBH}_{3} \mathrm{CN}(1.6), \mathrm{MeCHO} \\
\text { (6.4), } \mathrm{AcOH} \text { (1.5), } \mathrm{MeOH}, \mathrm{rt}, \\
2 \mathrm{~h}\end{array}$ & $7 \mathrm{~g}$ & 87 & $>99: 1$ \\
\hline 10 & $4 e$ & S & \multicolumn{2}{|c|}{$\mathrm{CH}_{2} \mathrm{CH}_{2} \mathrm{CH}_{2}$} & \multicolumn{2}{|c|}{$\mathrm{CH}_{2} \mathrm{CH}_{2} \mathrm{CH}_{2}$} & Et & $\begin{array}{c}\mathrm{NaBH}_{3} \mathrm{CN} \text { (1.5), } \mathrm{EtCHO} \\
\text { (6.1), } \mathrm{AcOH} \text { (1.5), } \mathrm{MeOH}, \mathrm{rt}, \\
2 \mathrm{~h}\end{array}$ & $7 \mathrm{~h}$ & 95 & $>99: 1$ \\
\hline 11 & $4 e$ & S & \multicolumn{2}{|c|}{$\mathrm{CH}_{2} \mathrm{CH}_{2} \mathrm{CH}_{2}$} & \multicolumn{2}{|c|}{$\mathrm{CH}_{2} \mathrm{CH}_{2} \mathrm{CH}_{2}$} & $\mathrm{Ph}$ & $\begin{array}{c}\mathrm{NaBH}_{3} \mathrm{CN} \text { (3.1), } \mathrm{PhCHO} \\
\text { (6.1), } \mathrm{AcOH} \text { (3.1), } \mathrm{MeOH}, \mathrm{rt}, \\
2 \mathrm{~h}\end{array}$ & $7 \mathbf{i}$ & 93 & $>99: 1$ \\
\hline 12 & $4 f_{8}$ & $\mathrm{O}$ & \multicolumn{2}{|c|}{$\mathrm{CH}_{2} \mathrm{CH}_{2} \mathrm{CH}_{2}$} & \multicolumn{2}{|c|}{$\mathrm{CH}_{2} \mathrm{CH}_{2} \mathrm{CH}_{2}$} & Et & $\begin{array}{c}\mathrm{NaBH}_{3} \mathrm{CN} \text { (1.5), } \mathrm{EtCHO} \\
\text { (6.2), } \mathrm{AcOH} \text { (1.5), } \mathrm{MeOH}, \mathrm{rt}, \\
2 \mathrm{~h}\end{array}$ & $7 \mathbf{j}$ & 68 & $99: 1$ \\
\hline 13 & $3 \mathbf{g}^{h}$ & S & $\mathrm{Me}$ & $\mathrm{H}$ & $\mathrm{CH}_{2} \mathrm{CH}$ & $\mathrm{H}_{2} \mathrm{CH}_{2}$ & $\mathrm{Me}$ & $\begin{array}{c}\mathrm{NaBH}_{4}(6.1), \mathrm{AcOH}(65.4) \\
\text { THF, rt, } 24 \mathrm{~h}\end{array}$ & $7 \mathrm{k}$ & 85 & $-i$ \\
\hline 14 & $3 g^{h}$ & S & $\mathrm{Me}$ & $\mathrm{H}$ & $\mathrm{CH}_{2} \mathrm{CH}$ & $\mathrm{H}_{2} \mathrm{CH}_{2}$ & Et & $\begin{array}{c}\mathrm{NaBH}_{4} \text { (6.1), EtCOOH (62.2), } \\
\text { THF, rt, } 24 \text { h }\end{array}$ & 71 & 68 & $-j$ \\
\hline 15 & $4 h^{k}$ & S & $\mathrm{Me}$ & $\mathrm{Me}$ & $\mathrm{CH}_{2} \mathrm{CH}$ & $\mathrm{H}_{2} \mathrm{CH}_{2}$ & Et & $\begin{array}{c}\mathrm{NaBH}_{3} \mathrm{CN} \text { (1.5), } \mathrm{EtCHO} \\
\text { (6.0), } \mathrm{AcOH} \text { (1.5), } \mathrm{MeOH}, \mathrm{rt}, \\
2 \mathrm{~h}\end{array}$ & $7 \mathrm{~m}$ & 96 & $>99: 1$ \\
\hline 16 & $3 k$ & $\mathrm{O}$ & $\mathrm{Ph}$ & $\mathrm{H}$ & $\mathrm{H}$ & $\mathrm{Ph}$ & $\mathrm{Me}$ & $\begin{array}{c}\mathrm{NaBH}_{4} \text { (10.1), } \mathrm{AcOH}(208.4), \\
\text { THF, rt, } 24 \mathrm{~h}\end{array}$ & $7 \mathrm{n}$ & 94 & 2:98 \\
\hline
\end{tabular}

${ }^{a}$ Level of conversion of the starting material is $100 \% .{ }^{b}$ Number in parentheses is the number of equivalents. ${ }^{c}$ Isolated yield. ${ }^{d} \mathrm{dr}$-cis/trans-diastereomeric ratio according to ${ }^{1} \mathrm{H}$ NMR spectroscopic data for the crude product. ${ }^{e} \mathrm{~A} 92: 8$ mixture of $\left(5 R^{*}, 5 \mathrm{a} R^{*}\right)$ - and $\left(5 S^{*}, 5 \mathrm{a} R^{*}\right)$-diastereomers (ref. [19]). ${ }^{f} \mathrm{~A}$ 91:9 mixture of $\left(5 R^{*}, 6 R^{*}, 7 R^{*}\right)$ - and $\left(5 S^{*}, 6 R^{*}, 7 R^{*}\right)$-diastereomers. \& A 99:1 mixture of $\left(6 R^{*}, 7 S^{*}\right)$ - and $\left(6 R^{*}, 7 R^{*}\right)$-diastereomers. ${ }^{h} \mathrm{~A} 60: 40$ mixture of $\left(5 R^{*}, 5 \mathrm{a} R^{*}\right)$ - and $\left(5 S^{*}, 5 \mathrm{a} R^{*}\right)$-diastereomers (ref. [19]). ${ }^{i} \mathrm{~A}$ 61:39 mixture of $\left(5 R^{*}, 6 R^{*}, 7 R^{*}\right)$ - and $\left(5 S^{*}, 6 R^{*}, 7 R^{*}\right)$-diastereomers. ${ }^{j} \mathrm{~A} 58: 42$ mixture of $\left(5 R^{*}, 6 R^{*}, 7 R^{*}\right)$ and $\left(5 S^{*}, 6 R^{*}, 7 R^{*}\right)$-diastereomers. ${ }^{k} \mathrm{~A} 98: 2$ mixture of $\left(6 R^{*}, 7 S^{*}\right)$ - and $\left(6 R^{*}, 7 R^{*}\right)$-diastereomers.

Generally, the two-step approach to 1-alkyl-substituted 1,2,4-triazepane-3-thiones/ones $(3 \rightarrow 4$ $\rightarrow 7$ ) was more effective. For instance, following this method compound $7 \mathrm{~g}$ was obtained from $3 \mathrm{c}$ in $82 \%$ overall yield, while direct reductive alkylation of $3 \mathrm{c}$ with the $\mathrm{NaBH}_{4} / \mathrm{AcOH}$ system gave $7 \mathrm{~g}$ only in $31 \%$ yield.

The structures of compounds $\mathbf{7 a}-\mathbf{n}$ were confirmed by spectroscopic data. The relative configurations of the stereogenic centers in $\mathbf{7 g}-\mathbf{n}$ were assigned by analysis of proton coupling constants in the triazepane ring as described above for compounds 4 . 


\section{Conclusions}

A convenient stereoselective synthesis of $N$-unsubstituted 1,2,4-triazepane-3-thiones/ones based on the reduction of readily available 2,4,5,6-tetrahydro-3H-1,2,4-triazepine-3-thiones/ones with sodium cyanoborohydride in $\mathrm{MeOH}$ at $\mathrm{pH} 3$ has been developed. Stereochemistry of the reduction was explained in terms of steric control approach of $\mathrm{BH}_{3} \mathrm{CN}$-anion to N1-protonated substrate. The obtained 1,2,4-triazepane-3-thiones/ones were converted into 1-alkyl-substituted derivatives by reductive alkylation with sodium cyanoborohydride and aldehyde in $\mathrm{MeOH}$ in the presence of AcOH. Alternatively, 1-alkyl-1,2,4-triazepane-3-thiones/ones were prepared with high stereoselectivity by treatment of tetrahydrotriazepines with sodium borohydride and excess of carboxylic acid in THF.

Acknowledgements: This research was financially supported by the Russian Foundation for Basic Research (Grant No. 19-316-70006).

\section{References and Note}

1. Sharp, J.T. Seven-membered Rings with Two or More Heteroatoms. In Comprehensive Heterocyclic Chemistry; Katritzky, A.R., Rees, C.W., Eds.; Pergamon: Oxford, UK, 1984; Volume 7, pp. 593-651.

2. Tsuchiya, T. Seven-membered Rings with Three Heteroatoms 1,2,4. In Comprehensive Heterocyclic Chemistry II; Katritzky, A.R., Rees, C.W., Scriven, E.F.V., Eds.; Elsevier: Oxford, UK, 1996; Volume 9, pp. 309-331.

3. Yranzo, G.I.; Moyano, E.L. Seven-membered Rings with Three Heteroatoms 1,2,4. In Comprehensive Heterocyclic Chemistry III; Katritzky, A.R., Ramsden, C.A., Scriven, E.F.V., Taylor, R.J.K., Eds.; Elsevier: Amsterdam, The Netherlands, 2008; Volume 13, pp. 399-430.

4. Peet, N.P. Monocyclic and Condensed Triazepines and Tetrazepines. In The Chemistry of Heterocyclic Compounds; Rosowsky, A., Ed.; John Wiley: New York, NY, USA, 1984; Volume 43, Part 2, pp. 719-842.

5. Léna, G.; Guichard, G. Synthetic Methods for the Preparation of Triazepandiones and Review of their Applications. Curr. Org. Chem. 2008, 12, 813-835.

6. Elattar, K.M.; Abozeid, M.A.; Mousa, I.A.; El-Mekabaty, A. Advances in 1,2,4-triazepines chemistry. RSC Adv. 2015, 5, 106710-106753.

7. McDonald, I.M.; Austin, C.; Buck, I.M.; Dunstone, D.J.; Gaffen, J.; Griffin, E.; Harper, E.A.; Hull, R.A.D.; Kalindjian, S.B.; Linney, I.D.; et al. Discovery and Characterization of Novel, Potent, Non-Peptide Parathyroid Hormone-1 Receptor Antagonists. J. Med. Chem. 2007, 50, 4789-4792.

8. McDonald, I.M.; Austin, C.; Buck, I.M.; Dunstone, D.J.; Griffin, E.; Harper, E.A.; Hull, R.A.D.; Kalindjian, S.B.; Linney, I.D.; Low, C.M.R.; et al. Novel, Achiral 1,3,4-Benzotriazepine Analogues of 1,4Benzodiazepine-Based CCK 2 Antagonists That Display High Selectivity over CCK 1 Receptors. J. Med. Chem. 2006, 49, 2253-2261.

9. Kaur, K.; Talele, T.T. 3D QSAR studies of 1,3,4-benzotriazepine derivatives as $\mathrm{CCK}_{2}$ receptor antagonists. J. Mol. Graph. Model. 2008, 27, 409-420.

10. Sankaran, M.; Kumarasamy, C.; Chokkalingam, U.; Mohan, P.S. Synthesis, antioxidant and toxicological study of novel pyrimido quinoline derivatives from 4-hydroxy-3-acyl quinolin-2-one. Bioorg. Med. Chem. Lett. 2010, 20, 7147-7151.

11. Ibrahim, S.M.; Abo-Kul, M.; Soltan, M.K.; Barakat, W.; Helal, A.S. Synthesis and Biological Screening of New Derivatives of 2,3-dihydro quinazolin-4(1H)-one and Benzotriazepin-5(2H)-one for Central Nervous System Activity. Med. Chem. 2014, 4, 351-356.

12. Ibrahim, S.M.; Baraka, M.M.; El-Sabbagh, O.I.; Kothayer, H. Synthesis of new benzotriazepin-5(2H)-one derivatives of expected antipsychotic activity. Med. Chem. Res. 2013, 22, 1488-1496.

13. Zhao, C.; Sham, H.L.; Sun, M.; Stoll, V.S.; Stewart, K.D.; Lin, S.; Mo, H.; Vasavanonda, S.; Saldivar, A.; Park, C.; et al. Synthesis and activity of $N$-acyl azacyclic urea HIV-1 protease inhibitors with high potency against multiple drug resistant viral strains. Bioorg. Med. Chem. Lett. 2005, 15, 5499-5503.

14. Sham, H.L.; Zhao, C.; Stewart, K.D.; Betebenner, D.A.; Lin, S.; Park, C.H.; Kong, X.-P.; Rosenbrook, W.; Herrin, T.; Madigan, D.; et al. A Novel, Picomolar Inhibitor of Human Immunodeficiency Virus Type 1 Protease. J. Med. Chem. 1996, 39, 392-397.

15. Hodge, C.N.; Fernandez, C.H.; Jadhav, P.K.; Lam, P.Y. Preparation of substituted caprolactams and derivatives useful for treatment of HIV disease. WO 9422840, 1994; Chem. Abstr. 1994, 123, 33104. 
16. Lantzsch, R.; Arlt, D. Herstellung und Reaktionen von 1,1-Dimethyl-3-oxobutyl-isocyanat. Synthesis 1977, 11, 756-757.

17. Mosher, W.A.; Toothill, R.B. Investigation of Routes to Indeno[2,1-f]-2H-1,2,4-triazepinediones. J. Heterocycl. Chem. 1971, 8, 209-214.

18. Fesenko, A.A.; Grigoriev, M.S.; Shutalev, A.D. Synthesis of aryl substituted 2,4,5,6-tetrahydro-3H-1,2,4triazepine-3-thiones/ones starting from chalcone-derived $\beta$-isothiocyanato ketones. Tetrahedron, 2016, 72 , $7952-7967$.

19. Fesenko, A.A.; Shutalev, A.D. Base-promoted ring expansion of 3-aminopyrimidine-2-thiones into 1,2,4triazepine-3-thiones. Tetrahedron 2016, 72, 2560-2573.

20. Danilkina, N.A.; Mikhaylov, L.E.; Ivin, B.A. Reaction of Acetylenedicarboxylic Acids Esters with 4,5Dihydro-1H-pyrazole-1-carbothioamides and 3,4,5,6-Tetrahydro-2H-1,2,4-triazepine-3-thiones. Chem. Heterocycl. Compd. 2011, 47, 886-900.

21. Rezessy, B.; Zubovics, Z.; Kovács, J.; Tóth, G. Synthesis and structure elucidation of new thiazolotriazepines. Tetrahedron 1999, 55, 5909-5922.

22. Richter, P.; Steiner, K. Chalcone as Starting Material for Synthesis of 1,2,4-Triazepines. In Studies in Organic Chemistry; van der Plas, H.C., Ötvös, L., Simonyi, M., Eds.; Elsevier: Amsterdam, The Netherlands, 1984; Volume 18, pp. 217-220.

23. Neidlein, R.; Ober, W.D. Synthesen von Siebenerringsystemen aus substituierten Isothiocyanaten und Hydrazinen. Monatsh. Chem. 1976, 107, 1251-1258.

24. Zigeuner, G.; Fuchsgruber, A.; Wede, F. Notiz zur Struktur des Umsetzungsproduktes von 4-Isothiocyanato4-methyl-2-pentanon mit Hydrazin - Uber das 2,4,5,6-Tetrahydro-5,5,7-trimethyl-3H-1,2,4-triazepin-3-thion. Monatsh. Chem. 1975, 106, 1495-1497.

25. Hassan, M.M.; Othman, E.S.; Abass, M. 3-Acetyl-4-methylthioquinolin-2(1H)-one as useful synthon intermediate for synthesis of some new quinolinones. Res. Chem. Intermed. 2013, 39, 1209-1122.

26. Chaudhary, A.; Joshi, S.C.; Singh, R.V. Studies on Therapeutically Relevant Tin(II) and Lead(II) Complexes of Schiff Base Macrocyclic Ligands Containing Thiosemicarbazone Moiety. Main Group Met. Chem. 2004, $27,59-70$.

27. Ibrahim, S.S.; El-Gendy, Z.M.; Allimony, H.A.; Othman, E.S. New Quinolones and Naphthyridinones Bearing Heterocyclic Rings. Chem. Papers 1999, 53, 53-64.

28. Hasnaoui, A.; Lavergne, J.-P.; Viallefont, P. Condensation des composés $\beta$-dicarbonylés avec les thiosemicarbazides. Recl. Trav. Chim. Pays-Bas 1980, 99, 301-306.

29. Hasnaoui, A.; Lavergne, J.-P.; Viallefont, P. Syntheses de nouvelles triazépines-1,2,4. J. Heterocycl. Chem. 1978, 15, 71-75.

30. Stanovnik, B.; Tišler, M. Zur Reaktion von 1,1,3,3-Tetraäthoxypropan mit Thiosemicarbaziden. Naturwissenschaften 1965, 52, 207.

31. Losse, G.; Farr, W. Synthese und Reaktionen der Heptriazinone. J. Prakt. Chem. 1959, 8, $298-305$.

32. Ebnöther, A.; Jucker, E.; Rissi, E.; Rutschmann, J.; Schreier, E.; Steiner, R.; Süess, R.; Vogel, A. Über Azetidin2,4-dione (Malonimide). Helv. Chim. Acta 1959, 42, 918-955.

33. Losse, G.; Hessler, W.; Barth, A. Ringschlussreaktionen mit Thiosemicarbaziden. Chem. Ber. 1958, 91, 150157.

34. Seebacher, W.; Michl, G.; Weis, R. Synthesis of new triazepinethiones. Tetrahedron Lett. 2002, 43, 7481-7483.

35. Hassan, A.A.; Bebair, T.M.; El-Gamal, M. Synthesis of pyrazolylthiazole and pyrazolyl-1,2,4-triazepine derivatives. J. Chem. Res. 2014, 38, 27-31.

36. Aly, A.A.; Hassan, A.A.; El-Sheref, E.M.; Mohamed, M.A.; Brown, A.B. Conventional and Microwave Irradiation Assisted Synthesis of New 1,2,4-Triazepine-3-thiones. J. Heterocycl. Chem. 2008, 45, 521-526.

37. El-Helby, A.A.; Amin, M.A.; El-Sawah, M.M.; Bayoni, A.H.; El-Azab, A.S.; Sherbiny, F.F. Synthesis and Microbiological Testing of Some New Derivatives of Compounds Containing Active Methylene Group. J. Saudi Chem. Soc. 2006, 10, 77-93.

38. Abdel-Ghany, H.; Khodairy, A.; Moustafa, H.M. Novel Synthesis of Some Spiro Heterocycles Derived from 3-Hydroxy-3-(2-oxocyclohexyl)-indolin-2-one. Synth. Commun. 2000, 30, 1257-1268.

39. Kobayashi, M.; Tanaka, J.; Katori, T.; Marsuura, M.; Yamashita, M.; Kitagawa, I. The Absolute Stereostructure of Swinholide A, a Potent Cytotoxic Dimeric Macrolide from the Okinawan Marine Sponge Theonella swinhoei. Chem. Pharm. Bull. 1990, 38, 2409-2418. 
40. Hosmane, R.S.; Bhadti, V.S.; Lim, B.B. Synthesis of a Novel Ring-Expanded Xanthine Analogue and Several Methyl or Benzyl Derivatives Containing the 5:7-Fused Imidazo[4,5-e][1,2,4]triazepine Ring System. Synthesis 1990, 1990, 1095-1100.

41. Trafimova, L.A.; Zimin, M.O.; Shutalev, A.D. Thiocarbamate-based synthesis of 2,4,5,6-tetrahydro-3H1,2,4-triazepine-3-thiones. J. Chem. Res. 2017, 41, 149-156.

42. Fesenko, A.A.; Shutalev, A.D. Different modes of acid-catalyzed cyclization of 4-( $\gamma$-oxoalkyl)semicarbazide hydrazones: 7-membered versus 14-membered cyclic semicarbazones formation. Tetrahedron 2015, 71, 9528-9543.

43. Losse, G.; Uhlig, H. Neue Siebengliedrige Heterocyclen auf Thiosemicarbazidbasis. Chem. Ber. 1957, 90, 257-260.

44. Losse, G.; Wottgen, E.; Just, H. Substituierte 7gliedrige Heterocyclen mit mehreren Heteroatomen. J. Prakt. Chem. 1958, 7, 28-37.

45. Hutchins, R.O.; Hutchins, M.K. Reduction of $\mathrm{C}=\mathrm{N}$ to $\mathrm{CHNH}$ by Metal Hydrides. In Comprehensive Organic Synthesis; Trost, B.M.; Fleming, I., Eds.; Pergamon: Oxford, UK, 1991; Volume 8, pp. 25-78.

46. Hemmer, R.; Lürken, W. Amine. In Houben-Weyl Methods of Organic Chemistry; Thieme: Stuttgart, Germany, 1992; Volume E16d, pp. 646-1234.

47. Andersson, P.G.; Munslow, I.J. (Eds.) Modern Reduction Methods; Wiley-VCH Verlag: Weinheim, Germany, 2008.

48. Nugenta, T.C.; El-Shazly, M. Chiral Amine Synthesis - Recent Developments and Trends for Enamide Reduction, Reductive Amination, and Imine Reduction. Adv. Synth. Catal., 2010, 352, 753-819.

49. Layer, R.W. The Chemistry of Imines. Chem. Rev., 1963, 63, 489-510.

50. Tripathi, R.P.; Verma, S.S.; Pandey, J.; Tiwar, V.K. Recent development on catalytic reductive amination and applications. Curr. Org. Chem. 2008, 12, 1093-1115.

51. Hutchins, R.O.; Hutchins, M.K.; Crawley, M.L. Sodium Cyanoborohydride. In e-EROS: Encyclopedia of Reagents for Organic Synthesis; John Wiley \& Sons: Weinheim, Germany, 2007; doi:10.1002/047084289X.rs059.pub2.

52. Seyden-Penne, J. Reductions by the Alumino- and Borohydrides in Organic Synthesis, 2nd ed.; Wiley-VCH: New York, NY, USA, 1997.

53. Lane, C.F. Sodium Cyanoborohydride-A Highly Selective Reducing Agent for Organic Functional Groups. Synthesis 1975, 3, 135-146.

54. Hutchins, R.O.; Natale, N.R. Cyanoborohydride. Utility and Applications in Organic Synthesis. A Review. Org. Prep. Proced. Int. 1979, 11, 201-246.

55. Borch, R.F.; Bernstein, M.D.; Durst, H.D. The Cyanohydridoborate Anion as a Selective Reducing Agent. J. Am. Chem. Soc. 1971, 93, 2897-2904.

56. Fesenko, A.A.; Grigoriev, M.S.; Shutalev, A.D. Nucleophile-Mediated Ring Expansion of 5-Acylsubstituted 4-Mesyloxymethyl-1,2,3,4-tetrahydropyrimidin-2-ones in the Synthesis of 7-Membered Analogues of Biginelli Compounds and Related Heterocycles. J. Org. Chem. 2017, 82, 8085-8110.

57. Fesenko, A.A.; Shutalev, A.D. 2,3-Dihydro-1H-1,3-diazepin-2-ones: synthesis and novel rearrangements into pyrrole derivatives. Tetrahedron Lett. 2014, 55, 1416-1420.

58. Fesenko, A.A.; Trafimova, A.A.; Shutalev, A.D. Synthesis of functionalized tetrahydro-1,3-diazepin-2-ones and 1-carbamoyl-1H-pyrroles via ring expansion and ring expansion/ring contraction of tetrahydropyrimidines. Org. Biomol. Chem. 2012, 10, 447-462.

59. Fesenko, A.A.; Shutalev, A.D. Nucleophile-mediated ring expansion of 4-chloromethyl- and 4mesyloxymethyl-5-tosyl-1,2,3,4-tetrahydropyrimidin-2-ones to 6-tosyl-2,3,4,5-tetrahydro-1H-1,3- diazepin2-ones: the effect of the leaving group and the substituent at C6. Tetrahedron 2011, 67, 6876-6882.

60. Fesenko, A.A.; Tullberg, M.L.; Shutalev, A.D. General approach to 6-tosyl-2,3,4,5-tetrahydro- 1H-1,3diazepin-2-ones via nucleophile-mediated ring expansion of tetrahydropyrimidines. Tetrahedron 2009, 65, 2344-2350.

61. Solovyev, P.A.; Fesenko, A.A.; Shutalev, A.D. A new synthesis of 4- or/and 6-CF3-containing hexahydroand 1,2,3,4-tetrahydropyrimidin-2-ones. J. Fluor. Chem. 2016, 182, $28-33$.

62. Fesenko, A.A.; Shutalev, A.D. A novel access to pyrido[4,3-d]pyrimidine scaffold via Staudinger/intramolecular aza-Wittig reaction of 5-acyl-4-( $\beta$-azidoalkyl)-1,2,3,4-tetrahydropyrimidin- 2ones. Tetrahedron 2014, 70, 5398-5414. 
63. Fesenko, A.A.; Shutalev, A.D. Synthesis of $\gamma$-Azido- $\beta$-Ureido Ketones and their Transformation into Functionalized Pyrrolines and Pyrroles via Staudinger/aza-Wittig Reaction. J. Org. Chem. 2013, 78, 1190-1207.

64. Fesenko, A.A.; Dem'yachenko, E.A.; Fedorova, G.A.; Shutalev, A.D. A novel selective synthesis of $\beta$ isothiocyanato ketones through a Staudinger/aza-Wittig reaction of $\beta$-azido ketones. Monatsh. Chem. 2013, 144, 351-359.

65. Fesenko, A.A.; Solovyev, P.A.; Shutalev, A.D. A novel convenient synthesis of 5-acyl-1,2dihydropyrimidin-2-ones via 4-trichloromethyl-1,2,3,4-tetrahydropyrimidin-2-ones. Tetrahedron 2010, 66, 940-946.

66. Fesenko, A.A.; Shutalev, A.D. Diastereoselective synthesis of 5-benzylthio- and 5mercaptohexahydropyrimidin-2-ones. Tetrahedron Lett. 2007, 48, 8420-8423.

67. Shutalev, A.D.; Kurochkin, N.N. A new approach to the synthesis of Biginelli compounds. Mendeleev Commun. 2005, 15, 70-72.

68. Gribble, G.W.; Nutaitis, C.F. Sodium Borohydride in Carboxylic Acid Media. A Review of the Synthetic Utility of Acyloxyborohydrides. Org. Prep. Proced. Int. 1985, 17, 317-384.

69. Abdel-Magid, A.F.; Carson, K.G.; Harris, B.D.; Maryanoff, C.A.; Shah, R.D. Reductive Amination of Aldehydes and Ketones with Sodium Triacetoxyborohydride. Studies on Direct and Indirect Reductive Amination Procedures. J. Org. Chem. 1996, 61, 3849-3862.

70. Baxter, E.W.; Reitz, A.B. Reductive Aminations of Carbonyl Compounds with Borohydride and Borane Reducing Agents. Org. React. 2002, 59, 1-714.

71. Abdel-Magid, A.F.; Mehrman, S.J. A Review on the Use of Sodium Triacetoxyborohydride in the Reductive Amination of Ketones and Aldehydes. Org. Proc. Res. Dev. 2006, 10, 971-1031.

(C) 2019 by the authors. Licensee MDPI, Basel, Switzerland. This article is an open access article distributed under the terms and conditions of the Creative Commons Attribution (CC BY) license (http://creativecommons.org/licenses/by/4.0/). 